Part of Journal of Research of the National Bureau of Standards, Volume 14, June 1935

\title{
EFFECT OF SULPHURIC ACID ON CHROME-TANNED LEATHER
}

\author{
By Everett L. Wallace, John Beek, Jr., and Charles L. Critchfield
}

\section{ABSTRACT}

Chrome-tanned leather contains a definite amount of acid in combination with the chromium and hide substance. The ratio of chromium to acid affects some of the properties of the leather. This investigation determined the effect of varying percentages of added sulphuric acid on the tensile strength of one lot of chrome-tanned leather, aged at $70^{\circ} \mathrm{F}$ and 65 percent relative humidity, for a period of 2 years. The maximum amount of sulphuric acid added, approximately 2.5 percent, caused little change in tensile strength. The pH of the eather with the largest amount of added acid was 2.8 and the basicity 47 percent.

CONTENTS

I. Introduction _._.

II. Material and methods

III. Results and conclusions

\section{INTRODUCTION}

In the manufacture of one-bath chrome-tanned leather, a basic salt of chromium sulphate is the usual tanning agent. In the tanning process this salt is decomposed by the hide substance with the liberation of free sulphuric acid. As the tanning progresses this acid must be partially neutralized to complete the tannage and fix the chrome salt in the hide. Some physical properties of chrome leather are influenced to a large extent by the ratio of chromium to acid in the finished product.

When chrome leather is exposed to an atmosphere polluted with sulphur dioxide, its sulphuric-acid content increases. Frey and Beebe ${ }^{1}$ showed that exposure to gas fumes may result in serious deterioration of chrome-tanned leathers, although the deterioration is not as great as for vegetable-tanned leathers under the same condition.

The purpose of the present investigation was to determine the effect of added sulphuric acid on the deterioration of chrome-tanned leather with age. The tensile strength of the leather was used as the criterion of deterioration as in similar work ${ }^{2}$ on vegetable-tanned leathers.

\section{MATERIAL AND METHODS}

The leather was prepared in the National Bureau of Standards' experimental tannery from steer hides by a commercial one-bath chrome-tanning process. The chemical analysis of the leather is given in table 1. 


\section{TABLE 1.-Chemical analysis of leather}

[Results expressed in percent, except pH. Total sulphate is expressed as sulphuric acid]

Chromium oxide $\left(\mathrm{Cr}_{2} \mathrm{O}_{3}\right) \ldots$

Total ash _._.

Grease (petroleum-ether extract) _...

Total sulphate (Thomas method)

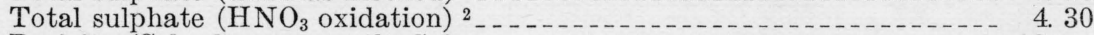

Basicity (Schorlemmer method) ${ }^{3}$

$\mathrm{pH}(5-\mathrm{g}$ of leather in $100 \mathrm{ml}$ of distilled water)

The leather was divided into four lots for the acid treatment, as described by Bowker, Wallace, and Kanagy. ${ }^{4}$ In this investigation each average tensile strength given in the results represents 21 instead of 42 samples.

The $\mathrm{pH}$ and added acid for the three lots of treated leather are given in table 2 .

TABLE 2.-Analysis of treated leather

\begin{tabular}{|c|c|c|c|}
\hline \multirow[b]{2}{*}{ Lot } & \multirow[b]{2}{*}{$\mathrm{pH}$} & \multicolumn{2}{|c|}{ Added acid as found by - } \\
\hline & & $\begin{array}{l}\text { Thomas } \\
\text { method }\end{array}$ & $\begin{array}{l}\text { Oxidation } \\
\left(\mathrm{HNO}_{3}\right)\end{array}$ \\
\hline $\begin{array}{l}1 \\
2 \\
3\end{array}$ & $\begin{array}{l}\text { 3. } 30 \\
\text { 3. } 09 \\
2.84\end{array}$ & $\begin{array}{c}\text { Percent } \\
\mathrm{H}_{2} \mathrm{SO}_{4} \\
0.95 \\
1.76 \\
2.62\end{array}$ & $\begin{array}{r}\text { Percent } \\
\mathrm{H}_{2} \mathrm{SO}_{4} \\
0.84 \\
1.55 \\
2.29\end{array}$ \\
\hline
\end{tabular}

The added acid is expressed as percentage of sulphuric acid on the basis of the dry leather immediately after it is added. The aging and tensile-strength determinations were carried out as previously described.

\section{RESULTS AND CONCLUSIONS}

The results of the tensile-strength determinations are given in table 3.

TABLE 3.-Results of tensile-strength determinations calculated in $1 \mathrm{~b} /$ in. $^{2}$

\begin{tabular}{|c|c|c|c|c|c|c|}
\hline \multirow{2}{*}{ Lot } & \multirow{2}{*}{ Untreated } & \multicolumn{5}{|c|}{ Age of treated samples (in months) - } \\
\hline & & 0 & 6 & 12 & 18 & 24 \\
\hline 0 & $\begin{array}{l}2,344 \\
2,518 \\
2,672 \\
2,456\end{array}$ & $\begin{array}{r}a, 657 \\
2,600 \\
2,633 \\
2,414\end{array}$ & $\begin{array}{l}2,513 \\
2,594 \\
2,601 \\
2,486\end{array}$ & $\begin{array}{l}2,446 \\
2,250 \\
2,450 \\
2,370\end{array}$ & $\begin{array}{l}2,600 \\
2,560 \\
2,675 \\
2,415\end{array}$ & $\begin{array}{l}2,290 \\
2,420 \\
2,470 \\
2,275\end{array}$ \\
\hline
\end{tabular}

a Treated with water for control.

1 J. Am. Leather Chem. Assn. 15, 504 (1920).

$2 \mathrm{~J}$. Am. Leather Chem. Assn. 26, 444 (1931).

3 J. Am. Leather Chem. Assn. 19, 575 (1924).

4J. Research NBS 14, 121 (1935) RP761. J. Am. Leather Chem. Assn. 30, 91 (1935). 
The effect of the acid after 24 months' aging is shown in figure 1, in which the percentage retention of tensile strength is plotted against the original $\mathrm{pH}$ of the leather. As the probable error of each of the points shown is 2 or 3 percent, it may be seen that there can be no certainty that the added acid caused deterioration. Thus, this investigation does not determine the limit of acidity beyond which chrometanned leathers deteriorate seriously in two years' time. It is apparent, however, that the chrome-tanned leather was very much less

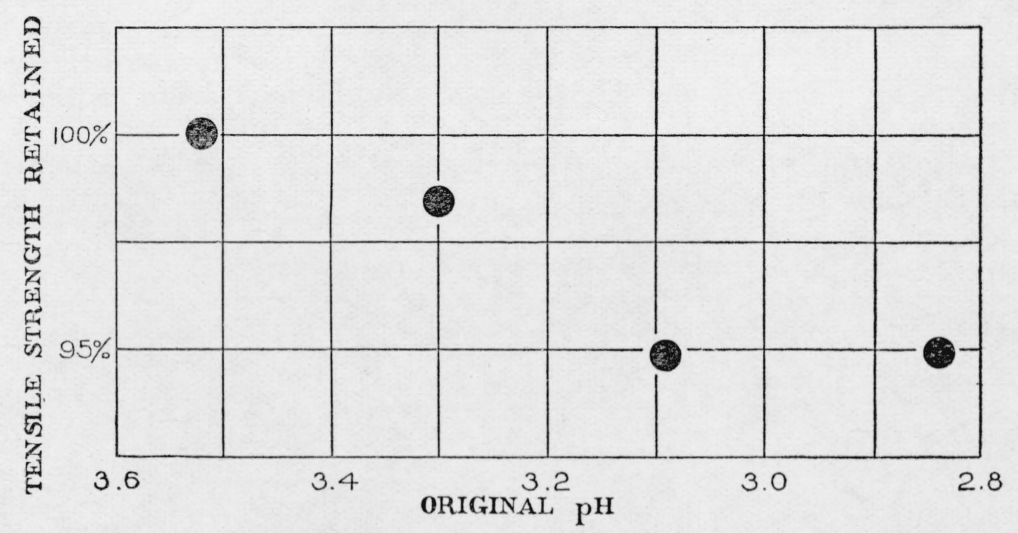

FIgURE 1.-Percentage of original tensile strength of the leather retained after two years aging as a function of its original $\mathrm{pH}$.

affected by the addition of sulphuric acid than were the vegetabletannedsleathers in the previous work. The remaining basicity of the leather with the highest acid content used in the present work may be significant in this connection. The leather containing approximately 2.5 percent of added acid had a basicity of 47 percent, as compared with 66 percent for the original leather, so that it might be expected that the acid was largely neutralized by the excess of basic chromium present.

Washington, April 16, 1935. 